\title{
Estimating Exchange Rate Effects on Exports: A Cautionary Note
}

\author{
Michael T. Belongia
}

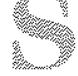

the abandonment of fixed exchange rates in the early 1970 , the value of the U.S. dollar has gained increasing prominence in domestic and intemational economic policy discussions. The dollar's value generally fell against other curencies between 1973 and 1979 ; its deelining value reduced U.S consumers' purchasing power as prices of imported goods rose relative to domestically produced items. At the same time, U.S. industries that relied heavily on foreign sales, such as agriculture and manulacturing, benefitted as prices of U.S. goods fell relative to prices offered bv competing exporters.

This situation was reversed from 1979 to early 1985 when the dollar made its persistent rise. Analysts now cite the dollar's historically high and rising value during this period as a fundamental, if not the primary, cause of declining producer incomes and loss of jobs in the L.S. agricultural and manufacturing industries in recent vears.

While analysts generally agree on the qualitative aspects of the exchange rate's effect on U.S. exports, the actual magnitude and persistence of these effects are subject to considerable controversy. This article demonstrates that one source of this disagreement reflects differences arising from the use of various exchange rate indexes. Using U.S. agriculural exports as an example, this article shows that an analysis based on different exchange rate measures can render substantially different conclusions about the U.S competitive position in world markets, the estimated effects of changes in the dollar's value on exports and the relationship between the exchange rate and other economic variables.

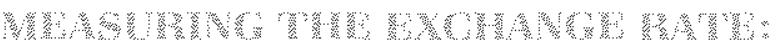 W O}

In examining the effect of exchange rate movements on exports, it is tempting to consider the exports of specific commodities 10 specific countries on a case- by-case basis. For example, if the U.S. exported corn only to France, Germany and Japan, it might seem reasonable to assume that only changes in bilateral exchange rates - that is, changes in the dollar's value against the franc, deutsche mark (dm) and ven individually - affect exports to these countries. Yet this approach would be misleading.

Aside from practical difficulties inherent in handing large numbers of bilateral rates simulaneously, changes in relative prices, including the relative prices of currencies, induce many forms of substitution among producers, consumes and nations. For example, a change in the value of the dollar that lased the price of U.S. relative to foreign corn would cause importers of U.S. con lo impont com from another country or to substitute other grains in place of com in production and consumption. This relative price change also would give foreign corn produces an incentive to increase corn production. U.S. produces's receiving a higher dollar denominated price for their corn would face a similar incentive - at least in the short run - to shilt resources from other crops into com production. Simply looking at a variety of bilateal exchange rate movements will not capture fully these many and diverse substitution possibilities: 10 accomplish this, one needs a single measure of changes in the collar's value relative to multiple arrencies.'

In the same way that the consumer price index repaesents a weighted sum of a specific sample of many individual retail prices, an exchange rate index is a weighted sum of the dollar's price in terms of a specifie sample of foreign curencies. The weights used typically are the percent of total U.S. trade con-

Michael T. Belongia is a senior economist at the Federal Reserve Bank of St. Louis. David J. Flanagan provided research assistance.

'This judgment, of course. abstracts from the many well-known problems with index numbers, including the use of fixed weights, and choice of base period, sample of countries and mathematical tormula. 
Table 1

Percentage Weights Assigned to Major Currencies in Five USS. Dollar Exchange Rate Indexes

\begin{tabular}{|c|c|c|c|c|c|}
\hline \multirow[b]{2}{*}{ Country } & \multicolumn{5}{|c|}{ Exchange Rate lidex } \\
\hline & FAB & MERM & SDR & Ma & USDA \\
\hline Germany & 20.8 & 1302 & 328 & 10.9 & 8.99 \\
\hline Japan & 136 & 2125 & 224 & 232 & 2105 \\
\hline France & 131 & 101 & 224 & 59 & 265 \\
\hline Unted Kingdom & 119 & 506 & 224 & 92 & 463 \\
\hline Canada & 9 & 2028 & 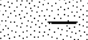 & 303 & 8,31 \\
\hline faly & 90 & 747 & 4 & 4 & 478 \\
\hline Netrerlands & 83 & 324 & 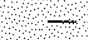 & 30 & 1126 \\
\hline Belgium & 64 & 244 & 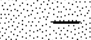 & 35 & 259 \\
\hline Sweden & 42 & 2,3 & 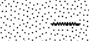 & 17 & ?ै: \\
\hline Swizenand & 36 & 169 & 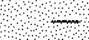 & 28 & 117 \\
\hline Australla & 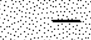 & 486 & 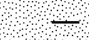 & 24 & 14 \\
\hline $\mathrm{MexeO}$ & 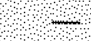 & 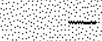 & 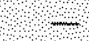 & 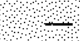 & 337 \\
\hline Spain & $\stackrel{?}{?}$ & 244 & 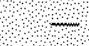 & 14 & 3,67 \\
\hline SouthKorea & 3 & 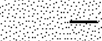 & 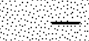 & 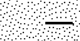 & 465 \\
\hline Denmank & 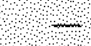 & 140 & ?. & 0.6 & 0.95 \\
\hline Allother & $?$ & 4.01 & $\rightarrow$ & 10 & 2193 \\
\hline TOTAL & 1000 & 10000 & 1000 & 1000 & 10000 \\
\hline
\end{tabular}

ducted with the individual countries selected. Currencies chosen for the sample usually are those of the countries that make up the five or ten largest shares of total U.S. foreign trade, For example, excluding imports from consideration, if the United States exported only com and France bought half, while Germany and Japan each bought 25 percent, an index of the dollar's value could be constructed by multiplying the franc dollar, dm/dollar and yen/dollar bilateral exchange rates by $1 / 2,1 / 4$ and $1 / 4$, fespectively, and adding up the resulting figures. The sum would be an export trade-weighted index of the dollar's value against the curencies of these three countries.

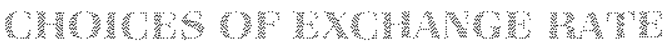

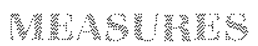

A variety of alternative trade-weighted exchange rate indexes have been constructed and used. Among the best-known are those produced by the Federal Reserve Board (FRB), Morgan Guaranty (MG), the U.S. Department of Agriculture (USDAl, the International Monetary fund (MERM and one constructed from Enternational Monetay Fund data on Special Dawing Rights ISDR. Table 1 indicates the weights that each of these indexes assigns to different foreign curencies. The most narrow index is the SDR index, which as- signs weights based on the four other currencies tbesides the U.S. dollan that make up SDRs."

The FRB, MERM and MG indexes base their weights primarily on trade with the G-10 countries and Switzerland: These indexes reflect trade among developed, industrialized economies but do not include lessdeveloped countries' (LDC) currency values." The MERM and MG indexes, however, are somewhat more broadly based than the FRB index in that they include Australia, Spain and several other countries. The USDA index has the broadest coverage, with more than 35 percent of its weight given to non-G-10 countries. This index, based only on trade in agricultural products, is designed specifically to assess changes in the competitiveness of U.S. agricultumal products as the dollar rises or falls. Especially notable in the USDA index are

2SDRs are the International Monetary Fund's official unit of account and serve as an international reserve asset often used in place of gold for making international payments. Since SDRs are denominated in terms of only the U.S. and four other nations' currencies. however, a dollar exchange rate based on SDR weights reflects changes in the dollar against a very small range of currencies.

The Group of Ten, or G-10, countries include Belgium, Canada, France, West Germany, Italy, Japan, the Netherlands. Sweden, the United Kingdom and the United States.

"A less-developed country typically is defined as one in which per capita income is less than one-fifth of U.S. per capita income. 


\section{Differences Between Arithmetic and Geometric Means}

The Federal Reserve Board changed the computation of its exchange rate index from one using arifhmetic means to one using geometric means. The Board dropped the practice of using arithmetic means because, as currencies diverged from each other over time, changes in currencies that rose against the dollar had a reduced impact on the index while changes in currencies that fell against the dollar had an increased impact on the index. As a result afithmetic averaging imparted a systematic upward bias to the measurement of changes in the dollar's average exchange value."

The two formulas for calculating the index value at time $t$ can be written as:

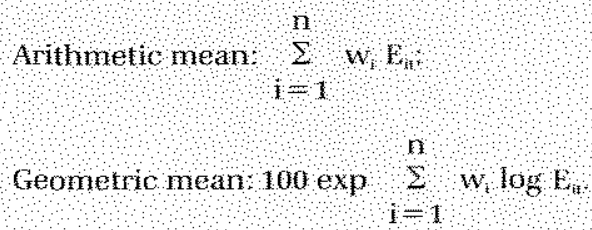

As mentioned in the text, the arithmetic mean is a simple sum of n cumency values ( $\mathrm{f}$ ) weighted by

See Federal Reserve Bulleth I ugus $1978, \mathrm{p}, 700$

the relatively large weights given to the Netherlands and such LDCs as Mexico and South Korea.

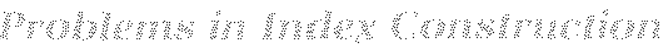

Constructing a multilatera exchange rate index is a difficult marriage of theory and practice. ${ }^{5}$ For example, choosing a base year for an index is difficult because, in theory, this base should be one in which absolute purchasing power parity holds and the countries used to construct the exchange rate index consume identical commodity bundles. It generally is not possible, however, to find a year in which absolute purchasing power parity held or actual consumption bundles across countries were identical.

Other practical problems associated with constructing an exchange rate index include the choice of

"See Dutton and Grennes (1985) for a detated discussion of theoretical and statistical issues concerning the construction of exchange rate indexes. A similar discussion focusing on agricultural tradeweighted indexes is in Goolsby and Roberson (1985).

${ }^{6}$ Absolute purchasing power maintains that the exchange rate will be at a value that equates the price levels between nations. each currencys weight $w_{i}$ in the index. The geometric mean, in contrast averages the percentage changes in the individual exchange rates to determine the percentage change in the index.

The difference between the formulas can be illustrated by a simple example. Consider observations for five exchange rates, each with an index weight equal to 0.2 at two points in time.
Time 1

$\mathrm{E}_{1}=100$

$\mathrm{E}_{2}=110$

$\mathrm{E}=90$

$\mathrm{E}_{1}=75$

$\mathrm{E}_{\mathrm{S}}=125$

Arthmetcmean 1000

Geometwe mean $=98.52$
Time 2

$L_{1}=100$

$\mathrm{L}_{2}-110$

$\mathrm{E}_{\mathrm{N}}=90$

$1+150$

$\mathrm{E}=125$

Arithmetic mean $=1150$

Geometric mean -11317
Using the same values, the two techniques produce different index values and, thus, growth rates. For example changing only $\mathrm{E}_{\text {, }}$ between time $\mathrm{I}$ and time 2 produces a 15 percent change in the arthmetic index and a 1487 percent change in the geometric index. Although this difference in the changes may seem small, similar changes will cause the gap between the two indexes to grow larger and larger over time.

weighting schemes and the mathematical differences among alternative index formulas: One particulary important distinction arises between indexes that are constructed using arithmetic means laaspevres and Pasche indexes vs. geometric means. Indexes constructed using arithmetic means give larger weights to those currencies that change more than other currencies in the index. In contrast, indexes created by geomelric means respond to proportional exchange rate movements. For example, an exchange rate index based on an arithmetic mean of 10 countries' exchange rates will change by more than an index based on the geometric mean of the same countries' currencies, if some countries' currency values change by much larger amounts than the others. Thus, even if two indexes are constructed from the same currencies and the same trade weights, the method used to calculate the index can produce different measures of changes in the dollar's value (see shaded box above for one example).

7 See Dutton and Grennes, pp. 20-27 
Chort 1

\section{Selected Real Effective Exchange Rates Expressed as Value of Dollar}

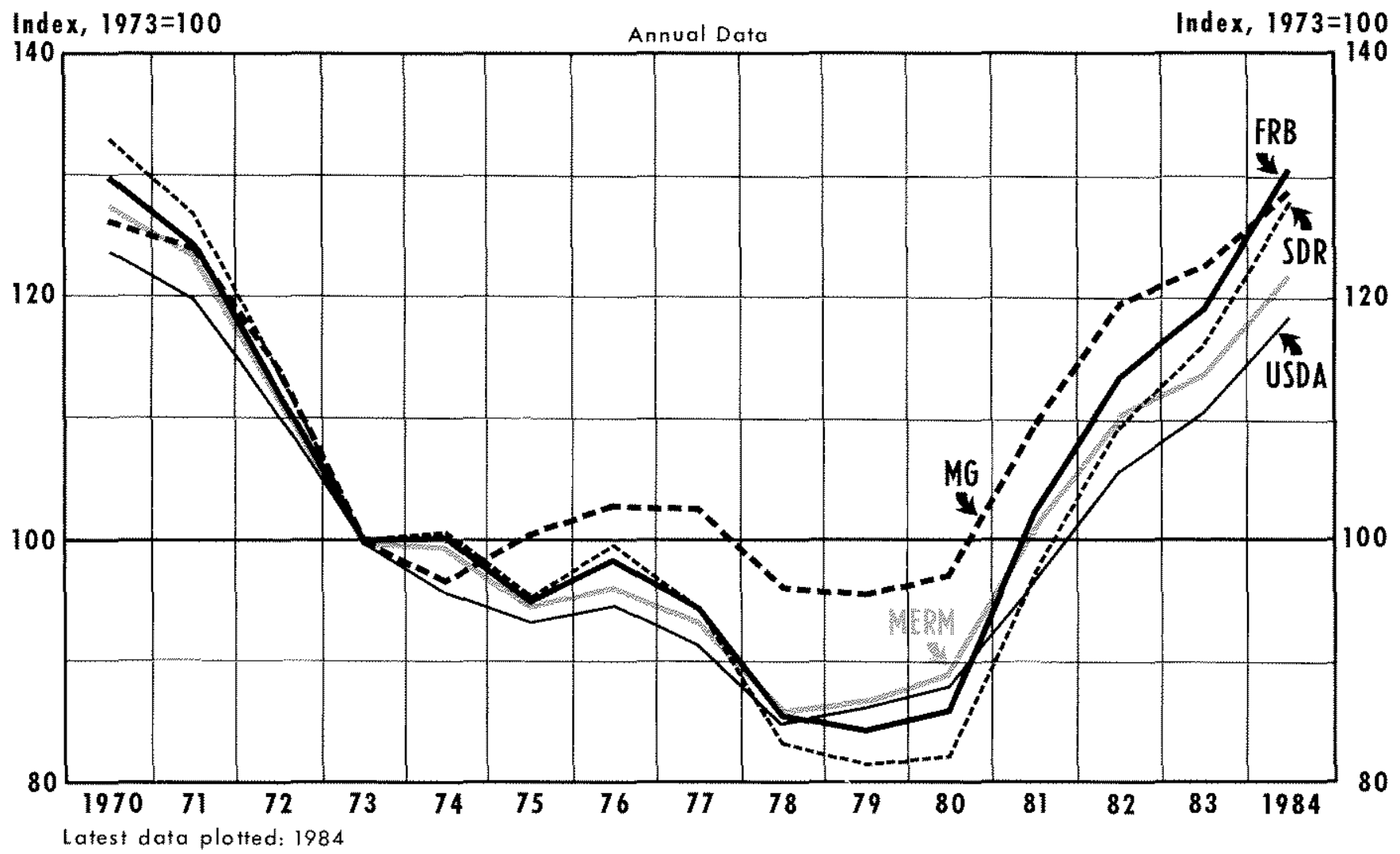

Lates data plotted: 1984

The difficulty of choosing an exchange ate measure for economic analvsis is perhaps best illustrated by the relationships in chat 1 and table 2 . Using measures of the real exchange rate, which are the nominal exchange rate indexes adjusted for differences in price levels between the United States and foreign countries, the chart shows that, between 1973 and 1980, the real value of the dollar fell as little as 3 percent based on the MCr measure, or by as much as 14 percent based on the FRB measure. Similarly, the chart indicates that the real value of the dollar rose by as much as 57 percent (FHB) or as little as 32 percent (MG) between 1980 and 1984.

The divergent behavior of these indexes also is evident in table 2. The top potion of the table indicates that the USDA index has the lowest average quarterly change, smallest standard deviation and smallest values for minimum and maximum changes. The SDR index, at the other end of the spectrum, has the largest values for three of these statistics; only the FRB index has a larger value for the mean quarterly change. The bottom portion of the table, which reports simple correlation coefficients, however, shows that changes in each index are correlated significantly. Overall, the data in chart 1 and table 2 indicate that, although movements in the indexes are positively comelated, there are substantial quantitative differences in their movements over time.

The problem of assessing the impact of exchange rate movements on exports might be somewhat ameliorated if there were a clear guide to choosing the best index. But, theoretical and statistical criteria that es- 


\section{Table 2}

\section{Summary Statistics for Changes in Alternative Real Exchange Rate Measures, I/1973-1/1985}

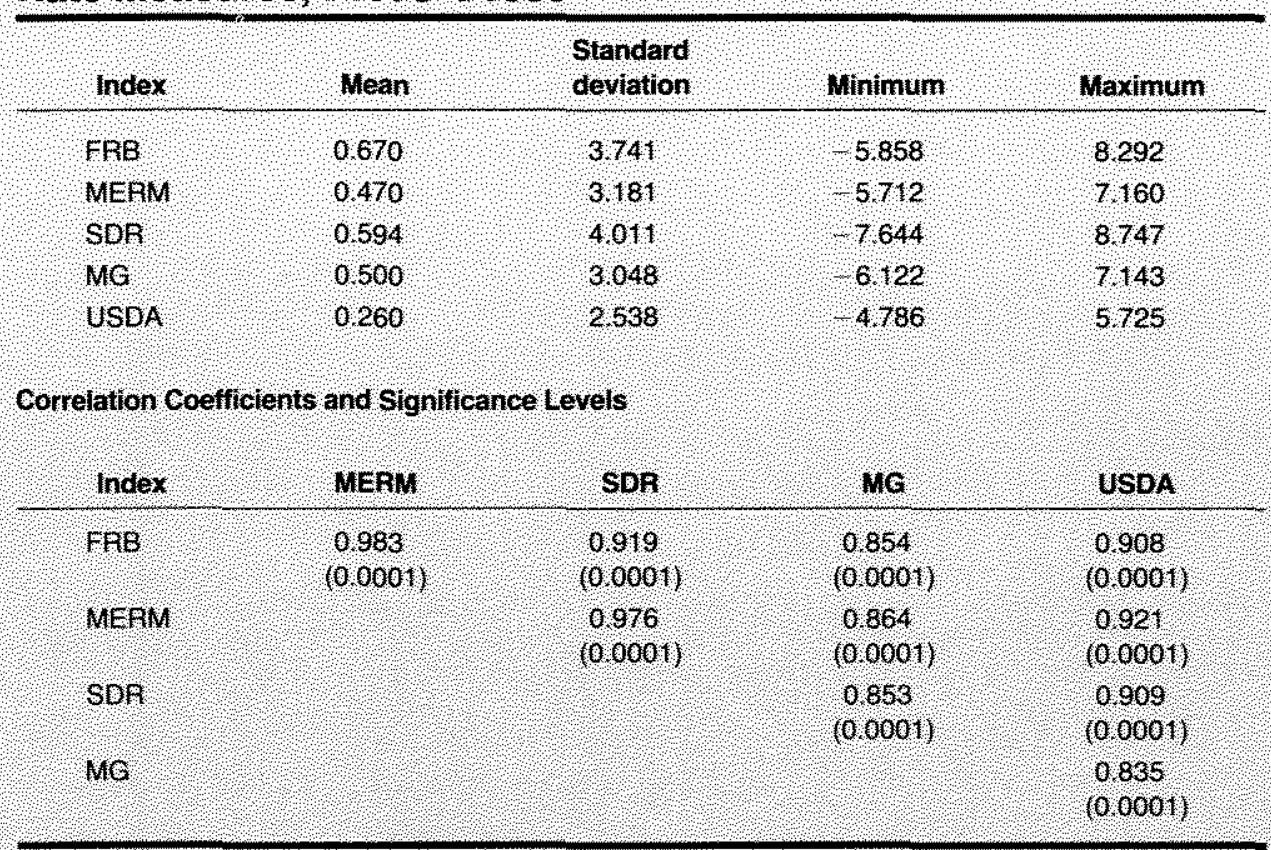

NOTE Signiticance levels in parentheses

tablish minimum standards of performance for an index do not offer clear guidelines for discriminating among alternative indexes that meet these basic standards. Without guidelines, two questions emerge: Does the choice of an index make a substantial difference in empirical work? If so, what other grounds might be used to choose the appropriate index? These questions are investigated below.

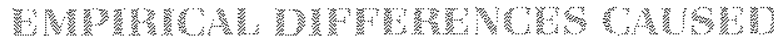

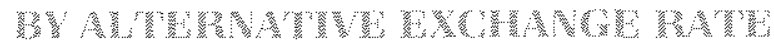

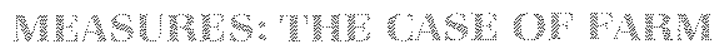

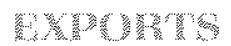

The real issue in estimating empirical relationm ships between exchange rates and exports depends not so much on the levels of the alternative exchange rate series, but on their specific changes over time. That is, if the various index levels differ by constant absolute amounts for constant proportions in logarithmsl, the magnitudes of the exchange rate coef-

${ }^{8}$ See Dutton and Grennes, pp. 8-11, for a discussion of these criteria ficient in an export equation will vary but the model's explanatory power will be the same across all measures. In contrast, if the exchange rate indexes are of similar magnitude but follow different paths around the same mean, both a model's exchange rate coefficient and its explanatory power will vary. The latter prospect is particularly relevant if an export equation derived from theory produces substantially different estimates of an exchange rate elasticity since there are no clear grounds, a priori, for preferring one single exchange rate index to another.

We can illustrate this problem by considering the case of farm exports. A general expression of the export demand for U.S. farm products can be written as:

$$
\begin{aligned}
& \text { (1) } \ln x_{1}=\alpha+\sum_{i=0}^{m} \beta_{i} \ln \operatorname{FGNP}_{\mathrm{s}-\mathrm{i}} \\
& +\sum_{j=1}^{p} y_{i} \ln \text { (USAGP/USCPU) } \\
& +\sum_{k=1}^{q} \delta_{1} \ln \operatorname{RER}_{t-k}+\varepsilon_{1 *}
\end{aligned}
$$




\section{Table 3}

\section{Estimates of Equation 1 Over a I/1973-IV/1981 Sample}

\begin{tabular}{|c|c|c|c|c|c|c|}
\hline $\begin{array}{l}\text { Exchange } \\
\text { rate }\end{array}$ & Intercept & $\Sigma$ In FGNP & In (USAGPIUSCPI) & $\Sigma$ In RER & $\mathbf{R}^{2}$ & DW \\
\hline $\mathrm{FRB}$ & $\begin{array}{l}4686 \\
(1,45)\end{array}$ & $\begin{array}{r}0.825 \\
(2.37) \\
2\end{array}$ & $\begin{array}{r}-020 \\
(525) \\
2\end{array}$ & $\begin{array}{r}-0.671 \\
(2.49)\end{array}$ & 0.93 & 160 \\
\hline MERM & $\begin{array}{l}14.396 \\
(21.22)\end{array}$ & $\square$ & $\begin{array}{r}-0.964 \\
(1+31) \\
8\end{array}$ & $\begin{array}{r}1597 \\
(12.59) \\
7\end{array}$ & 095 & 1.51 \\
\hline SOR & $\begin{array}{l}4316 \\
(151)\end{array}$ & $\begin{array}{r}0,809 \\
(2,47) \\
2\end{array}$ & $\begin{array}{r}-0.594 \\
(5.60) \\
2\end{array}$ & $\begin{array}{r}-0603 \\
(274) \\
3\end{array}$ & 093 & 161 \\
\hline $\mathrm{MG}$ & $\begin{array}{l}4108 \\
(419)\end{array}$ & $\begin{array}{l}1 / 779 \\
(12,48) \\
1\end{array}$ & $\begin{array}{r}0,365 \\
(4,16) \\
2\end{array}$ & a -2 & 091 & 116 \\
\hline USDA & $\begin{array}{r}1,229 \\
(0,24)\end{array}$ & $\begin{array}{l}(6) \\
(3,15) \\
\beta \\
2\end{array}$ & $\begin{array}{r}0,504 \\
(4,07) \\
8\end{array}$ & $\begin{array}{l}0226 \\
(0,45) \\
25\end{array}$ & 094 & 166 \\
\hline
\end{tabular}

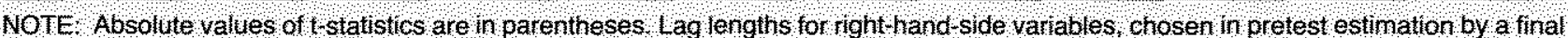
predicton eror (FPE) criterion are shown be ow the 1 -statistics.

where:

$$
\begin{aligned}
X & =\text { real exports of all U.S. fam commodities; } \\
\text { FGNP }= & \text { foreign real GNP; } \\
\text { USAGP = } & \text { index of U.S. farm prices; } \\
\text { USCPI = } & \text { index of U.S. consumer prices; } \\
\text { RER }= & \text { real, trade-weighted exchange rate, ex- } \\
& \text { pressed in foreign curency units per dol- } \\
& \text { lap; and } \\
\varepsilon & \text { a random error tem. }
\end{aligned}
$$

The model was estimated over several sample periods using quarterly data. ${ }^{16}$

The only difference among models was the choice of an index for the real exchange rate from the five series described in table 1 . Each index was rebased to have a common value of 100 in $L / 1973$. Tables 3 and 4 report these results. Results shown in table 3 apply to the first sample period, which ends in the fourth quarter of 1981 when real U.S. farm exports peaked; the second period results, reported in table 4 , cover the entire period of flexible exchange rates up to the

This export equation is derived and discussed in Batten and Belongia (1984). This article also contains more detaled discussion on the distinction between real and nominal exchange rates.

'DLag lengths for right-hand-side variables were chosen by an FPE criterion following procedures outlined in Batten and Thornton (1984). first quarter of 1985. The critical results are those showing the estimated elasticities of fatm exports with respect to the real exchange rate, which are shown in the fifth column of these tables. These values indicate the percentage change in real farm exports that will result from a 1 percent change in the real value of the dollar, as measured by the various indexes.

Although the general statistical characteristics and economic implications of the altemative models are broadly similar, there is considerable variation among the estimated elasticities, both across sample periods and across exchange rate measures. In table 3 , the estimated exchange rate elasticity varies from zero tno effectl for the $M G$ index and -0.23 for the USDA measure to -1.60 for the MERM index. Table 4 shows the estimated exchange rate elasticity varies from -0.80 (SDR) to -1.42 (MG). It also is interesting to note that extending the sample period raises the exchange rate elasticities for the MG and USOA indexes from zero and -0.23 , respectively, to -1.42 and -1.23 in contrast to other indexes, which do not exhibit the same sensitivity to choice of an estimation interval. Thus, using the same model, it is possible to show that the demand for U.S. farm exports is either elastic or inelastic merely by changing the measure of the dollar's value used in the analysis. Clearly, the estimated response of farm exports to changes in the dollar's real value is sensilive both to the choice of sample period and the specific exchange rate measure used. 


\section{Table 4}

\section{Estimates of Equation 1 Over a I/1973-1/1985 Sample}

\begin{tabular}{|c|c|c|c|c|c|c|}
\hline $\begin{array}{l}\text { Exchange } \\
\text { rate }\end{array}$ & Itercept & $2 \ln F G N P$ & $\Sigma \ln (U S A G P U S C P I)$ & Sn AER & $\overline{\mathbf{A}}^{2}$ & ow \\
\hline $\mathrm{FAB}$ & $\begin{array}{r}5.224 \\
(4.22)\end{array}$ & $\begin{array}{r}0819 \\
(5,65) \\
0\end{array}$ & $\begin{array}{r}0,643 \\
(701) \\
7\end{array}$ & $\begin{array}{r}0878 \\
(950)\end{array}$ & 093 & 183 \\
\hline MERM & $\begin{array}{r}9851 \\
(590)\end{array}$ & $\begin{array}{r}0,540 \\
(3,36) \\
2\end{array}$ & $\begin{array}{r}-0759 \\
(765) \\
8\end{array}$ & $\begin{array}{r}1,380 \\
(9,10) \\
7\end{array}$ & 093 & 178 \\
\hline SDA & $\begin{array}{l}5305 \\
(396)\end{array}$ & $\begin{array}{l}072 \\
(5,20) \\
0\end{array}$ & $\begin{array}{l}0,590 \\
(6,67) \\
3\end{array}$ & $\begin{array}{l}0796 \\
938 / \\
\beta\end{array}$ & 093 & 175 \\
\hline $\mathrm{nG}$ & $(4.61)$ & $\begin{array}{l}10.81)_{0} \\
0\end{array}$ & 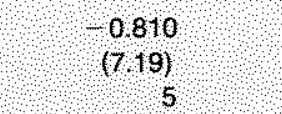 & 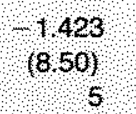 & 092 & 161 \\
\hline USDA & $\begin{array}{l}8451 \\
(4.81)\end{array}$ & $\begin{array}{l}0.630 \\
(3.68)\end{array}$ & $\begin{array}{c}0.698 \\
(6.48)\end{array}$ & $\begin{array}{l}1229 \\
(6.58)\end{array}$ & 0.92 & 149 \\
\hline
\end{tabular}

NOTE Absolute values of $t$ statstics are in parentheses. The number of lags for each ight hand side variable, chosen hi pretest estimation by a final production error (FPE) erterion, are shown below the s statistics, zero lags ndieate a contemporaneous. value ony

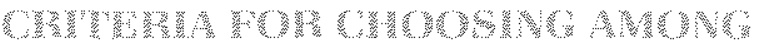 A ${ }^{2}$ W}

The previous discussion demonstrated that altemative exchange rate measures diverge widely over time and have different estimated effects on farm exports. Unfortunately, neither economic theory nor index theory provides a clear criterion for preferring one exchange rate measure to another. There are, however, two approaches that can be used to indicate which index is potentially more useful: its out-ofsample forecasting performance and its relationship to variables that are thought to affect its value.

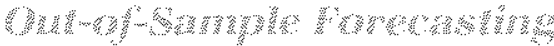

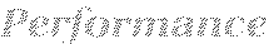

The descriptive statistics for the in-sample estimations of equation 1 do not provide clear grounds for preferring a particular exchange rate index. This inconclusiveness, as we noted, leaves open the question of the true magnitude of the exchange rate elasticity. The choice of an index, however, can be based on how well it predicts the future path of exports; thus, its outof -sample performance in predicting changes in farm exports is crucial. "Ihis criterion is examined in table 5 and chart 2

The statisties in table 5 are derived from the esti-
Table 5

Out-of-Sample Error Statistics for Projected Farm Exports Using Alternative Real Exchange Rate Series (V/1982-1/1985)

\begin{tabular}{|c|c|c|c|}
\hline $\begin{array}{l}\text { Exchange } \\
\text { rate series }\end{array}$ & $\begin{array}{l}\text { Mean } \\
\text { error }\end{array}$ & $\begin{array}{l}\text { Mean } \\
\text { absolute } \\
\text { error }\end{array}$ & RMSE \\
\hline $\mathrm{FBB}$ & -0032 & 0062 & 0074 \\
\hline MERM & 0021 & 0073 & 0099 \\
\hline $\mathrm{SOP}$ & 0044 & 0066 & 0080 \\
\hline $\mathrm{MG}$ & 10188 & 0190 & 0229 \\
\hline USDA & 10,224 & 0224 & 0211 \\
\hline
\end{tabular}

mated export equation coefficients reported in table 3. The estimated coefficients and the actual values for the equation's right-hand-side variables were used to simulate paths for farm exports over the period $1 / 1982$ to $1 / 1985$. The only difference among these allemative paths is the exchange rate measure used. Comparisons of actual farm exports over this interval with each of the simulated paths produce the erfor summary statistics reported in table $\mathbf{5}$. 
Chart 2

\section{Errors in Projected Farm Exports}

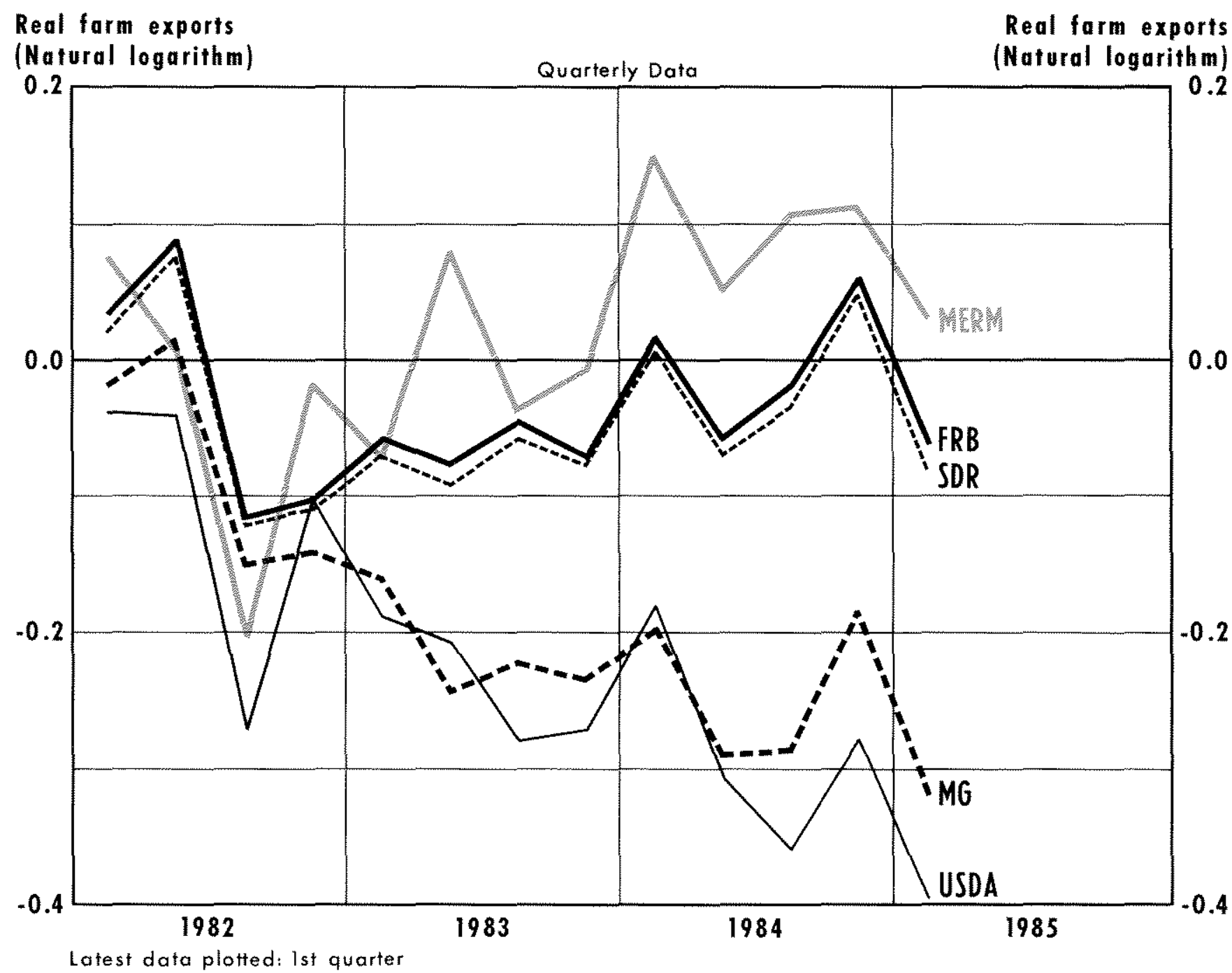

Lofest dafa plotted: 1st quarter

On the basis of these measures, the FRB, MERM and SDR series perform substantially better than the other two. Fronically, the USDA index, which is designed specifically for empirical work on farm exports, performs much worse than the other measures. Moreover, it is clear from chart 2 , which plots the out-ofsample actual minus predicted errors made in predicting farm exports, that the USUA index consism tently overpredicts fam expont volume by a substantial amount. The line denoted $M G$, which also indicates persistent overpredictions of exports, applies to the model that showed no significant exchange rate effect based on the MG index. These data point out why care must be laken in choosing a patticular exchange rate measure for use in empirical work and farm policy analyses that consider the expected future path of farm exports. Specifically, the data in table 5 and chart 2 indicate that, based on equation 1 and estimates of the MG or USDA index's future value, future farm exports would have been consistently overpredicted by large amounts, even if the exchange rate movement had been predicted perfectly."

11I should be noted that, as in the previous analysis, these error statistics coutd vary over sample periods and specifications of export demand equations. 


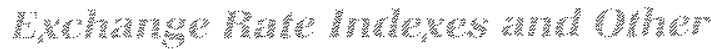

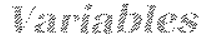

A second possible criterion for preferring one index to another is the index's relationship with variables thought to affect the dollar's value. This eriterion is important because projections of future exports necessarily involve some prediction of the dollar's future value. Faced with a choice between an exchange rate index that apparently shares no significant relationship with variables that, theoretically. should in fluence it and one that is related systematically to, say, changes in interest rates, one would prefer the latter index, all other things equal.

There currently is widespread debate among economists over what factors affect the exchange rate. $A$ faidy general theoretical model of intemational currency values, however, suggests four variables as the main influences. These include: differences in inflation rates between countries, differences in real rates of interest between countries, differences in real economic conditions that affect trade flows and differences in political or other risks associated with investments in different countries."

We return to this issue by investigating how each of the alternative exchange rate indexes responds to changes in variables that are proxies for the theoretical factors listed above.". The dependent variable in our investigation is the change in the various measures of the real exchange rate. To the extent possible, weights and countries used to compute each equation's righthand-side variables are the same as those used to calculate the real exchange rate measure."

The first model used can be written as:

$$
\begin{aligned}
& \text { (2) } \Delta \ln \mathrm{REH}_{2}=\alpha+\beta_{1} \Delta \mathrm{RLD}_{1}+\beta_{2} \Delta \mathrm{RID}_{\mathrm{m}, 1}+\beta_{1} \Delta \mathrm{\Sigma CAB} \\
& +\beta, \triangle \mathrm{SAB}_{i-1}+\varepsilon_{1}
\end{aligned}
$$

"These influences are derived from the general framework developed by Isard (1983). On the other hand, some economists who have investigated these relationships empirically have found changes in the exchange rate to behave as a random walk. See, for example. Meese ard Rogoff (1983) and Hakkio (1985).

${ }^{13}$ Derivations of these specifications are based on analyses in Hooper and Morton (1982). Shafer and Loopesko (1983), and Isard. Estimates for a broader range of specifications for the FRB index only are reported in Batten and Belongia (1986).

${ }^{14}$ Construction of the ex ante real interest differerstial, $\triangle \mathrm{RID}$, depended on the avalability of inflation forecasts for countries in the index. In those cases in which a country was not included in the OECD forecast survey, it was dropped from the analysis and all weights used to construct the index were expanded by a common proportion so the adjusted weights still summed to one. where

$\Delta \operatorname{lnRER}=$ the change in the $\log$ level of the real exchange rate;

$\Delta \mathrm{RID}=$ the change in the ex ante real interest rate differential between the U.S. and foreign countries;

$\triangle \mathrm{ZCAB}$ = the change in the U.S. cumulative curcent account balance; and

$\varepsilon_{1} \quad=$ a random enror tem.

Move detailed variable definitions and methods of construction appear in the appendix to this article. The subscript " $t$ " indicates quarterly time periods. Each equation was estimated over the III/1974--III/1984 time period; the estimation period is shorter because of the availability of OECD inflation forecasts needed to construct the RID variable.

The results reported in table 6 again reveal some differences among the altemative exchange rate measures. In general, the signs and magnitudes of hndiviual coefficients are similar across equations. for example, the contemporaneous and lagged tems for the current account balance are significant in each equa tion. In contrast the lagged real interest differential is significant only in the equations that use the FRB, MERM and USDA indexes. Overall, the MERM index demonstrates a slightly better fit than the other measures.

Another specification of changes in the real exchange rate maintains the arguments of the previous model and adds the effects of changes in the growth rates of the money stock both in the U.S. $(\Delta \Delta \ln M)$ and abroad $\left(\Delta \Delta \ln M^{*}\right)$. This expression can be written as:

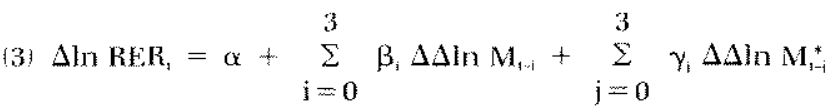

$$
\begin{aligned}
& +\sum_{k=0}^{3} \delta_{k}(\Sigma \mathrm{CAB})_{t-\mathrm{k}}+\sum_{\mathrm{p}=0}^{3} \tau_{\mathrm{k}} \Delta \mathrm{RID} \mathrm{D}_{1-\mathrm{k}}
\end{aligned}
$$

Although the summary statistics shown in table 7 indicate some difference in goodness-of-fit across equations, the divergence of the results' qualitative interpretations is more interesting. For example, changes in the growth rate of the U.S. money stock have significant effects on the SDR index, but not on the other four. Similarly, changes in the real interest differential exhibil significant effects on the FRB, SDR and MERM indexes, but not on the others. Finally, only the cumulative current account balance and intercept have a significant effect on the MG and USDA indexes. If we are looking for an exchange rate index that is related significantly to variables that economic theory 
Table 6

\section{Applications of a Common Exchange Rate Equation to Alternative Exchange Rate Indexes}

\begin{tabular}{|c|c|c|c|c|c|c|c|}
\hline $\begin{array}{l}\text { Exchange } \\
\text { rate }\end{array}$ & Intercept & $\triangle \mathrm{RD}_{\mathrm{t}}$ & $\triangle A D_{-1}$ & $\triangle \triangle \mathrm{CAB}$ & $\triangle \Sigma C A B_{-1}$ & $\bar{n}$ & DW: \\
\hline FRB & 0005 & $\begin{array}{l}0.001 \\
(071)\end{array}$ & $\begin{array}{l}0004 \\
(204)\end{array}$ & $\begin{array}{r}0.007 \\
(3.59)\end{array}$ & $\begin{array}{l}0008 \\
(342)\end{array}$ & 028 & 157 \\
\hline MEAM & $\begin{array}{r}0.004 \\
(094)\end{array}$ & $\begin{array}{l}0.001 \\
(0,63)\end{array}$ & $\begin{array}{l}0004 \\
(202)\end{array}$ & $\begin{array}{r}-0.006 \\
(3.80)\end{array}$ & $\begin{array}{l}0.007 \\
(3.60)\end{array}$ & 0.30 & 166 \\
\hline SDR & $\begin{array}{l}0,004 \\
(079)\end{array}$ & $\begin{array}{l}0001 \\
(0,46)\end{array}$ & $\begin{array}{l}0004 \\
(170)\end{array}$ & $\begin{array}{r}-0,007 \\
(3.54)\end{array}$ & $\begin{array}{l}0,009 \\
(338)\end{array}$ & 026 & 165 \\
\hline$M G$ & $\begin{array}{l}0,008 \\
(189)\end{array}$ & 0001 & $\begin{array}{l}0,003 \\
(170)\end{array}$ & $\begin{array}{r}-0005 \\
(327)\end{array}$ & $\begin{array}{l}0006 \\
(336)\end{array}$ & 023 & 190 \\
\hline$\cup 5 D A$ & $\begin{array}{l}0.005 \\
(127)\end{array}$ & $\begin{array}{r}0.001 \\
(0.78)\end{array}$ & $\begin{array}{l}0.003 \\
(218)\end{array}$ & $\begin{array}{l}0.005 \\
(3.47)\end{array}$ & $\begin{array}{l}0.005 \\
(326)\end{array}$ & 029 & 166 \\
\hline
\end{tabular}

NOTE Absolute values of t statistics in parentheses.

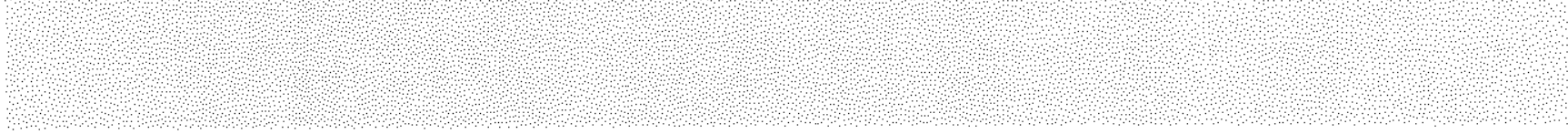

suggests should determine currency values, the MG and USDA series are the weakest candidates. ${ }^{15}$ Choices among the other three, however, remain problematical.

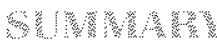

Changes in the exchange value of the dollar over the past six years have been attributed to a wide variety of economic developments. This article has shown, however, that determining how much the dollar has changed and what effect it has had on other variables can depend on the specific exchange rate index chosen for the analysis. Both the set of countries included in the index and the weighting scheme used to aggregate movements in foreign currency values will affect the interpretation.

Using farm exports as one example, the analysis showed that different exchange rate indexes produce large differences in the estimated effects of exchange rates on exports. Moreover, further analysis showed that different indexes exhibit substantial differences in their ability to predict future changes in the volume of exports. Finally, if one is interested in the effects of changes in money growth, interest rates, the cutrent account balance or other variables on the exchange

${ }^{15}$ Estimates of ther equations showed a similar diversity of results in which no right-hand-side variable was significant in all equations and different combinations of variables were significant across exchange rate measures. rate, one must realize that the significance and magnitude of such effects vary widely across exchange rate measures. Because neither economic nof statistical theory gives a clear indication of which exchange rate index is the "best" measure, these broad differences in results suggest that considerable caution be used in relying on a single exchange rate measure to indicate the effects of changes in the dollar's value on exports.

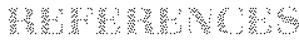

Batten, Dallas S., and Michael T. Belongia. "The Recent Decline in Agricuttural Exports: Is the Exchange Rate the Culprit?" this Review (October 1984). pp. 5-14

"Monetary Policy, the Real Exchange Rate and U.S. Agricuttural Exports," American Joumal of Agricultural Economics (May 1986), forthcoming.

Batten, Dallas S., and Daniel L. Thornton. "How Robust Are the Policy Conchusions of the St. Louis Equation?: Some Further Evidence," this Review (June/July 1984), pp. 26-32.

Dutton, John, and Thomas Grennes. "The Measurement of Effective Exchange Rates Appropriate for Agricultural Trade," Department of Economics and Business (November 1985), North Carolina State University.

Goolsby, O. Halbert, and Ronald R. Roberson. "Exchange Rate Developments and Their Impact on U.S. Agricultural Exports: 1970m84," U.S. Department of Agriculture, FAS Staff Report No. 5 (May 1985).

Hakkio, Craig. "Does the Exchange Rate Follow a Pandom Walk? A Monte Carlo Study of Four Tests for a Random Wak," Research Wotking Paper 85.02, Federal Reserve Bank of Kansas City (June 1985). 
Table 7

Applications of a Common Exchange Rate Equation to Alternative Exchange Rate Indexes

\begin{tabular}{|c|c|c|c|c|c|c|c|}
\hline $\begin{array}{l}\text { Exchange } \\
\text { rate }\end{array}$ & Intercept & $\sum_{i=0}^{3} \Delta \Delta \ln M_{m}$ & $\sum_{j=0}^{3} \Delta \sin M^{*}$ & $\sum_{k=0}^{3}(\Sigma C A B)_{k-k}$ & $\sum_{p=0} \sum_{0} \Delta$ IID $_{\mathrm{t}-\mathrm{p}}$ & $\overrightarrow{\mathbf{H}}^{2}$ & DW \\
\hline FPB & $\begin{array}{l}0.013 \\
(2.99)\end{array}$ & $\begin{array}{r}3.728 \\
(1.81)\end{array}$ & $\begin{array}{r}-0.959 \\
(0.63)\end{array}$ & $\begin{array}{r}0.001 \\
(4.31)\end{array}$ & $\begin{array}{l}0.020 \\
(2.72)\end{array}$ & 0.60 & 2.34 \\
\hline MERM & $\begin{array}{l}0.011 \\
(2.64)\end{array}$ & $\begin{array}{r}2.360 \\
(1.15)\end{array}$ & $\begin{array}{l}0.405 \\
(0.27)\end{array}$ & $\begin{array}{r}0.001 \\
(3.87)\end{array}$ & $\begin{array}{l}0.015 \\
(2.23)\end{array}$ & 0.52 & 2.24 \\
\hline SDA & $\begin{array}{l}0,012 \\
274)\end{array}$ & $\begin{array}{l}5202 \\
(246)\end{array}$ & $\begin{array}{r}-1715 \\
\therefore(120)\end{array}$ & $\begin{array}{r}0.002 \\
(4.69)\end{array}$ & $\begin{array}{r}0.026 \\
(329)\end{array}$ & 0.64 & 2.41 \\
\hline$M G$ & 0.013 & $\begin{array}{l}1300 \\
(0.61)\end{array}$ & $\begin{array}{r}0.596 \\
(042)\end{array}$ & $\begin{array}{r}0,001 \\
(3,13)\end{array}$ & 0.011 & 0.46 & 271 \\
\hline USDA & $\begin{array}{l}0011 \\
(323)\end{array}$ & $(1.836$ & $\begin{array}{r}0,145 \\
(0,12)\end{array}$ & $\begin{array}{l}0001 \\
(4,32)\end{array}$ & $\begin{array}{r}0009 \\
(175)\end{array}$ & 0.52 & 2.20 \\
\hline
\end{tabular}

NOTE Absolute values of $t$-statistics in parentheses

Hooper, Peter, and John Morton. "Fluctuations in the Dollar: A Model of Nominal and Real Exchange Rate Determination," Journal of international Money and Finance (April 1982), pp. 39-56.

Isard, Peter. "An Accounting Framewotk and Some issues For Modeling How Exchange Rates Respond to News," in Jacob A. Frenkel, ed. Exchange Rates and International Macroeconomics (University of Chicago Press, 1983), pp. 19-56.
Meese, Richard, and Kenneth Rogoff. "Empirical Exchange Rate Methods of the Seventies: Do They Fit Out of Sample?" Journal of International Economics (February 1983), pp. 3-24.

Shafer, Jeftrey, and Bonnie E. Loopesko. "Floating Exchange Rates After Ten Years," Brookings Papers on Economic Activity (1:1983), pp. 1-86.

(See appendix on next page) 
APPENDIX

\section{Definitions of Variables Used in Equations 1-3}

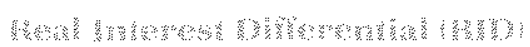

OECD forecasts of the CPI for individual countries for July are applied to quarters 1 and 2 ; forecasts for December are used for quarters 3 and 4 . These tradeweighted ex ante inflation differentials are then subtracted from a trade-weighted nominal interest differential using Morgan Guaranty Trust three- to four-month comparable money market rates.

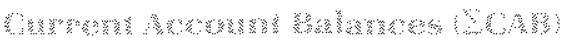

U.S. current account balance accumulated since 1970 ; billions of dollars.

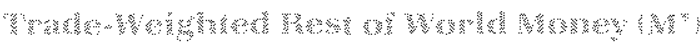

Money stock for various countries indexed to $\mathrm{I} / 1973$ and weighted by same trade weights used in construction of the respective exchange rate indexes.

${ }^{1}$ Trade-weights for each variable are those applied to the respective exchange rate indexes. All exchange rates are real and indexed to $1 / 1973=100$

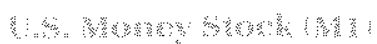

M1 indexed to $\mathrm{L} / 1973$.

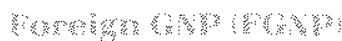

Foreign real GNP or GDP measures indexed to $1 / 1973$ and trade-weighted.

ㄴ.

U.S. real GNP indexed to $1 / 1973$.

and

Unit value of agricultural exports index: V/973= 100 .

(1)

U.S. consumer price index: $1 / 1973=100$. 